JIRI ALINA, Ph.D. ${ }^{1}$

E-mail: jalina@ef.jcu.cz

RICHARD D. MCGRATH, Ph.D. ${ }^{1,2}$

E-mail: rmcgrath@georgiasouthern.edu

IVANA FALTOVÁ LEITMANOVÁ, Ph.D. ${ }^{1}$

(Corresponding author)

E-mail: leitman@ef.jcu.cz

FILIP PETRÁCH, Ph.D. ${ }^{1}$

E-mail: petrach@ef.jcu.cz

${ }^{1}$ Faculty of Economics

University of South Bohemia

Studentská 13, 37005 České Budějovice, Czech Republic

${ }^{2}$ Parker College of Business

Georgia Southern University

11935 Abercorn Street, Savannah Georgia USA, 31419
Traffic Planning

Preliminary Communication

Submitted: 8 Feb. 2019

Accepted: 19 Feb. 2020

\title{
USING CONSTRAINTS IN FREIGHT VOLUME TO IDENTIFY REGIONAL NEEDS FOR ROADWAY INFRASTRUCTURE
}

\begin{abstract}
Policy decisions on the allocation of funds among sub-national regions for transportation infrastructure, specifically for motorways, face budgetary constraints and problems of geographical allocation. The purpose of this research is to assist the policymakers in efficiently allocating resources. The objective of this research is to test the ability of a limited model to identify regions whose freight transport capacity is constrained by lack of motorway infrastructure. This paper conducts an analysis of the relationship between freight transport volume, indicators of the demand for goods, indicators of congestion, and the availability of motorways and class one roadways across regions to determine if a model based on available data may inform the policymakers to effectively use limited funds and avoid unnecessary construction. The NUTS3 regions in the Czech Republic are used to estimate a preliminary model that may be generalized for the use across countries. The analysis finds sufficient variability across regions in the marginal effect of motorways on freight transport to assist the policymakers in determining which regions face the most economically severe constraints, and to separate the effects of population density from the lack of infrastructure. Although the Czech Republic is a developed country, there is significant emphasis, due to the increasing volumes of transportation flows, on the analysis of transportation in relation with the land use.
\end{abstract}

\section{KEY WORDS}

transportation infrastructure policy; freight transport; transportation demand; transportation economics; roadways and motorways; Czech Republic; regional economy; NUTS3;

\section{INTRODUCTION}

The systems of roadways must be capable of carrying the volume of traffic necessary to support the social and economic needs of the region and they must also be capable of withstanding the stress of heavy loads of freight. For the purpose of promoting economic growth, transportation policymakers have the primary role in funding the construction and upgrading of roads and motorways. With scarce financial resources, they must meet the current and future needs of the individual regions, and the nation as a whole, by allocating funds to their most valuable use.

The present research analyses road transport flows to determine the extent to which we can effectively measure the benefits of freight transport to, from, and within the regions in the Czech Republic. These benefits are dependent on many factors including the population density, technological sophistication, increased investment, etc. Multiple authors [1-3] find empirical evidence of a relationship between transport and positive regional economic and social effects. They also point out that the effects of the development of transport infrastructure may be very different across regions, a conclusion which will be borne out by this research. Klufova et al. [4] emphasize the need for normative approaches to evaluate unbalanced competition between bus and rail service on the main transport routes on subnational level in the Czech Republic due to the differences in the quality of transport infrastructure, 
the attractiveness of the region, and the economic potential for new investment and industrial development. The purpose of the present research is to test whether the data on transport infrastructure, freight volumes, and population density may be used to determine if the transformation infrastructure is constrained and needs improvement.

Sapkota [5] defines road network as all roads in the country including motorways, highways, main or national roads, secondary or regional roads, and other urban and rural roads. Substantial research concludes that the transport infrastructure has a greater impact than any other kind of infrastructure on the economic growth, productivity, and even on the reduction of poverty. Transport improvements decrease the transportation costs, improve access to markets and labour, foster economic integration, stimulate competition, support agglomeration economies and provide an array of wider economic benefits. At the aggregate level, efficient transportation reduces costs across many economic sectors, while inefficient transportation increases these costs.

Transport investments have multiple overlapping economic impacts, which can be assessed from several perspectives. As a contributor to economic development, transport infrastructure, by its very nature, has important impacts on intra-regional and inter-regional transport time and costs, and thus potentially on the location of households and businesses. Transport services are produced and consumed jointly with transport infrastructure. Road conditions were analysed by Hulten [6] who claims that a few bad roads may not pose serious problems in a road network because substitute routes are available, but a large number of roads in poor condition may give rise to bottlenecks that erode the effectiveness of the whole network.

Another distinguishing feature of the transport sector is that its function is primarily as an input to many other activities. Firms transport products to distribution centres and retail outlets; businesses send their employees to meet with customers, suppliers, regulators and co-workers; and people travel to work and for leisure pursuits [7].

Despite our understanding of these transportation issues for the economies with well-developed transport networks, little is known about the extent of the gains that result from the additions to the existing network. Direct evidence of the causal effects of such improvements on the economic activity using ex-post evaluation of improvements is rare $[8,9]$. The productivity of infrastructure is very important in contributing to the economic growth, but its marginal productivity is not constant. Factor productivity varies in both the quantity and quality of the factors of production; it is dependent upon the business cycle, and in which sector of the economy the factor is deployed [10]. Social exclusion from the lack of transport infrastructure negatively impacts the sub-regional economy and is considered the root cause of rural poverty. In this way, the population of poverty-ridden sub-regions becomes susceptible to physical and socioeconomic ills and is wedged into a deprivation cycle resulting in further depression of sub-regions [11]. Deng [12] studies the coordination of regional transport investment policies and the connectivity characteristics of transport infrastructure in relation to spillover effects that may either positively or negatively affect the productivity and economic growth in the neighbouring regions. For the national interest, the coordination issue is a major concern of the central government to maximize the net returns of transport investment across the regions, rather than focus on each region individually.

Large-scale investments in transport infrastructure affect spatial competitiveness and thus the economic growth of an urban area, a region, or a nation. To justify the infrastructure investments, both transport models and economic models are used to evaluate the interactions among production and consumption, often on a subnational level. Courtonne et al. [13] modelled and estimated indeterminateness of domestic shipping flows in France. Alina [14] analysed the usage of the speed-flow curve in traffic modelling. Krisztin [15] used a four-stage model of regional transportation planning for evaluating the transport needs and for creating and harmonization of the transport policy. Economic models incorporate the indirect effects of infrastructure investments, such as employment or economic growth [16]. The vast majority of studies dedicated to this topic indicate that constructing and improving the transport infrastructure contributes to productivity and economic growth. Research shows that the regional development is influenced by many factors including the quality of transport infrastructure and improved access to transport. This improves the accessibility to the markets in which companies operate, and may make weaker regions more attractive and create new jobs. In turn, this alleviates the out-migration from the poorer regions [1]. 
Multiple factors complicate the decision to fund the transportation infrastructure. Although these factors are not included in the empirical analysis in the present research, they must be noted as an important part of the discussion. One factor is the sources of funding. Urban regions consider investing in peripheral roadways that bypass the city centre in order to alleviate congestion, improve the local environment, and facilitate more efficient travel across the greater metropolitan area. Increasingly, such proposals are accompanied by tolling as a means of financing the new roadway. Although an optimal policy from an efficiency standpoint would be to toll both the centre-city roadway and the bypass in combination, the stakeholders and voter groups are effective in limiting the tolls to new roadways. Constructing a toll and compensation scheme to distribute the welfare gains tends to be a hindrance [17]. The funding of transportation infrastructure is further complicated by the desire to optimally allocate investments in the transportation infrastructure with respect to the flow of goods, the flow of people, and the support of the tourism industry [18].

Negative externalities related to roadway construction and use must also be noted, particularly with respect to the natural environment and the health and safety of the local population. Lorries are the primary means of freight transport and, although lorry technology and fuel quality are improving, lorries will remain the main cause of localized pollution in the near future [19]. Erjavec [20] discusses the undesirable effects of freight transport on the environment. The most recognized effect is the greenhouse gas $\left(\mathrm{CO}_{2}\right)$ emissions, but this is also substantial public interest in reducing noise and water pollution that affect the daily activities of local population. In $[20,21,22]$ it is argued that when transport firms internalize the cost of these externalities, it is possible to optimize their processes. Doll et al. [23] recommend that the transport of goods changes, when possible, from road transport to rail and ship for energy efficiency and to reduce the environmental externalities. Grazi et al. [24] summarized the tools for spatial planning and the development of policies focused on reducing GHG emissions in passenger and freight transportation. Bortas et al. [25] used a model with fuzzy logic to optimize the routes chosen for transport infrastructure based on multiple criteria including minimizing both cost and environmental impact.
In terms of traffic safety, high rates of vehicle usage and congestion due to under-developed transport infrastructure increase the number of road accidents in urban areas, particularly among the most vulnerable road users: pedestrians and cyclists. Kopits et al. [26] observe that as countries develop, death rates fall as healthcare for the young improves, but the traffic deaths are a notable exception as the growth in motor vehicles usage brings an increase in road fatalities.

With regard to demand for transport infrastructure, the input variables consist of a volume of passengers, freight and information, and the budgets of households and businesses. On the supply side of transport infrastructure, the variables consist of energy for different modes, budgets of governments, operators and providers, manpower for governments, operators and providers (inflow of personnel), equipment such as vehicles, information, education and construction material to build the infrastructure. The input and output of the transport system are closely related to the macro-environment [16]. Traditional methods of travel data collection are often limited by high costs, infrequent updates, or small sample sizes. Several emerging technologies, such as mobile phone positioning, global positioning system tracking, and Bluetooth re-identification, now allow for easier acquisition of long-term continuous trip data with little to no interaction with subjects. Growing interest in the use of these passive data collection techniques for travel modelling necessitates an evaluation of trends and concerns among researchers and practitioners [27].

Despite these confounding factors, the direct and indirect effects of transportation infrastructure have a net positive impact on the economic growth and development of a country. It also provides access to goods, services, and employment opportunities in these regions through macroeconomic multiplier effects [28].

The benefits of improved transport infrastructure include reduced commuter and freight travel times, and reduced transport costs. This increased transport accessibility, in turn, leads to a decrease in the marginal cost of producing and delivering goods, an increase in the volume of goods transacted, and an increase in the mobility of individuals. The present research attempts to identify interactions between transport and other economic characteristics and 
outcomes of the region that may be used by the transportation policymakers to guide to geographic distribution of infrastructure budgets.

\section{BASIC HYPOTHESES}

The authors wish to determine if available data may be used to provide the policy guidance on the relative needs of individual sub-national regions in the allocation of infrastructure funds. The key variables are:

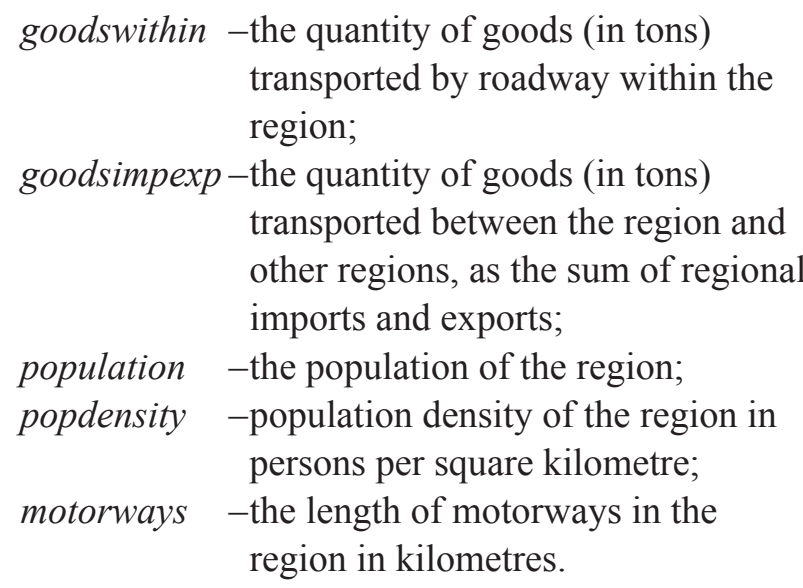

The authors approach the question of infrastructure constraints using three hypotheses, under the assumption that the quantity of goods transported within a region (goodswithin) will be positively correlated with population, which is the primary determinant of the demand and supply of goods to be shipped.

Population density (popdensity) is expected to be negatively correlated with goodswithin due to the effects of congestion such as non-commercial traffic on the efficiency of shipping.

H1(Null): goodswithin is uncorrelated with popdensity.

H1(Alt): goodswithin is negatively correlated with popdensity.

The second hypothesis to be tested relates goodswithin to goodsimpexp. It may be positively related with the transport of goods within the region as a measure of overall economic activity or it may show a negative sign due to the congestion caused by commercial traffic.

H2(Null): goodswithin is uncorrelated with goodsimpexp

H2(Alt-1): goodswithin is negatively correlated with goodsimpexp

$\mathrm{H} 2$ (Alt-2): goodswithin is positively correlated with goodsimpexp
The quantity of goods imported into and exported from the region are taken together because they jointly represent the effects of the movement of freight across the regional borders on the congestion and movement of freight within the region. The first alternate hypothesis is consistent with the argument that freight transport within a region is crowded out by commercial congestion of motorways from the movement of goods between regions. The second alternate hypothesis is consistent with an argument of complementarity of goods transport within and between regions.

Freight shipments are expected to be positively correlated with the length in kilometres of motorways in a specific region, but only to the extent that congestion constrains the flow of freight. In cases where infrastructure in the region is more than marginally sufficient, the infrastructure and freight shipments are expected to be uncorrelated. In contrast to Hypotheses 1 and 2, for which there is a single test across all regions, the motorway variables are constructed region by region, allowing us to test Hypothesis 3 separately for each region.

$\mathrm{H} 3$ (Null): goodswithin is uncorrelated with motorways

H3(Alt): goodswithin is positively correlated with motorways

Thus, the expectation is that $\mathrm{H} 3$ (Null) will be supported for some regions, while H3(Alt) will be supported in other regions. This will delineate those regions that are infrastructure constrained from those regions that have sufficient transportation infrastructure to support all the desired movement of goods. This test becomes the policy instrument to inform the policymakers of the potential for each region to benefit from adding motorway infrastructure.

\section{RESEARCH RESULTS AND PRESENTATION OF METHODS}

For each of the years from 2009 to 2016, for each of the NUTS3 regions in the Czech Republic, the following variables were retrieved from the Czech Statistical Office in the Albertina and Transport Yearbooks: The quantity of goods, in thousands of tons, imported to and exported from (goodsimpexp), and transported within (goodswithin) the region; the population and area of each region; and the length of motorways in kilometres. The descriptive statistics for each of these variables is found in Table 1 . 
Alina J, McGrath RD, Faltová Leitmanová I, Petrách F. Using Constraints in Freight Volume to Identify Regional Needs...

Table 1 - Descriptive statistics for variables in the analysis

\begin{tabular}{||c|c|c|c|c|c||}
\hline \hline Variable & Mean & Median & Maximum & Minimum & Std. Dev \\
\hline \hline goodswithin & $17,809.3$ & $15,293.3$ & $41,591.8$ & $6,093.1$ & $9,306.4$ \\
\hline goodsimpexp & $10,316.3$ & $8,860.6$ & $41,263.9$ & $3,051.8$ & $6,744.1$ \\
\hline population & $712,990.7$ & $587,446.5$ & $1,333,249.0$ & $297,317.0$ & $306,865.7$ \\
\hline area & $6,028.8$ & $5,339.0$ & $10,929.0$ & $3,163.0$ & $2,331.3$ \\
\hline popdensity & 123.4 & 118.2 & 230.1 & 63.2 & 42.6 \\
\hline motorways & 88.28306 & 73.51 & 346.62 & 4.587 & 87.64678 \\
\hline
\end{tabular}

Units: goodswithin, goodsimpexp in 1,000 tons; population in persons; area in sq. km.; motorways in $\mathrm{km}$.

The descriptive statistics presented in Table 1 includes both the within-region and between-region differences in variables. Thus, the maximum and minimum values for a particular variable for a specific region are likely to be somewhat close together, given the relatively short range of years for which the data are available.

These data were transformed to create the following variables: popdensity is the population density of each region calculated as the population divided by the area in square $\mathrm{km}$; and the motorways variable was transformed into a set of variables, motorways010 through motorways080, one for each region, in block diagonal form. The numerical codes at the end of each variable name are the designated NUTS3 codes for each region (Prague 010, Central Bohemian Region 020, South Bohemian Region 031, Plzeň Region 032, Karlovy Vary Region 041, Ústí nad Labem Region 042, Liberec Region 051, Hradec Králové Region 052, Pardubice Region 053, Vysočina Region 063, South Moravian Region 064, Olomouc Region 071, Zlín Region 072, and Moravian-Silesian Region 080). The block diagonal matrix has one column for each region. In the column for each region, the value equals zero for rows associated with all the other regions. Each row for the given region contains the kilometres of motorways in the region for that year. This allows a separate estimation of the marginal importance of roadway infrastructure for each region using all of the observations for that region, while using all observations across all regions to estimate the coefficients for goodsimpexp, population, and popdensity. In a fully specified model, a significant positive coefficient on the motorways variable for an individual region may be considered a signal that additional transport infrastructure spending in that region would be beneficial.

The model to be estimated is a linear equation of the form goodswithin $=f(c$, goodsimpexp, population, popdensity, motorways) where $c$ is a constant.
The model estimates goods transported within the region as a function of the length of motorways, the sum of goods imported and exported to the region, population, and population density.

The following equation was estimated by ordinary least squares using Eviews 8 statistical software. There were 8 observations, from 2009 to 2016, for each of thirteen NUTS3 regions for a total of 104 observations. Prague was excluded from the analysis due to its dramatically different economic and rural/urban structure compared to other regions.

goodswithin $=C+C(2) \cdot$ goodsimpexp +

$C(3) \cdot$ population $+C(4) \cdot$ popdensity +

$+C(5) \cdot$ motorways $020+C(6) \cdot$ motorways $031+$

$+C(7) \cdot$ motorways $032+C(8) \cdot$ motorways $041+$

$+C(9) \cdot$ motorways $042+C(10) \cdot$ motorways $051+$

$+C(11) \cdot$ motorways $052+C(12) \cdot$ motorways $053+$

$+C(13) \cdot$ motorways063 $+C(14) \cdot$ motorways064+

$+C(15) \cdot$ motorways $071+C(16) \cdot$ motorways072+

$+C(17) \cdot$ motorways080

The least-squares estimate of goodswithin reported in Table 2 provides a starting point for the analysis, and offers useful but mixed results. The quantity of goods exported and imported by road freight is positively correlated with goodswithin, suggesting that goodsimpexp might be interpreted as a measure of economic performance in the regional economy. The population and popdensity both have signs as expected, but neither is statistically significant. Population is positively correlated with freight transport due to both production and consumption, while population density adds to congestion with pedestrians, automobiles, and urban crowding, thus reducing the efficiency of freight transport. Both the coefficients and the statistical significance of the motorway variables suggest there is substantial inefficiency in the estimation of the model. Regions 41, $51,52,53,63,71$, and 72 have coefficients that are not significantly different from zero, suggesting that an increase in the length of roadway infrastructure 
Alina J, McGrath RD, Faltová Leitmanová I, Petrách F. Using Constraints in Freight Volume to Identify Regional Needs...

Table 2 - Estimation of goods transported within the region

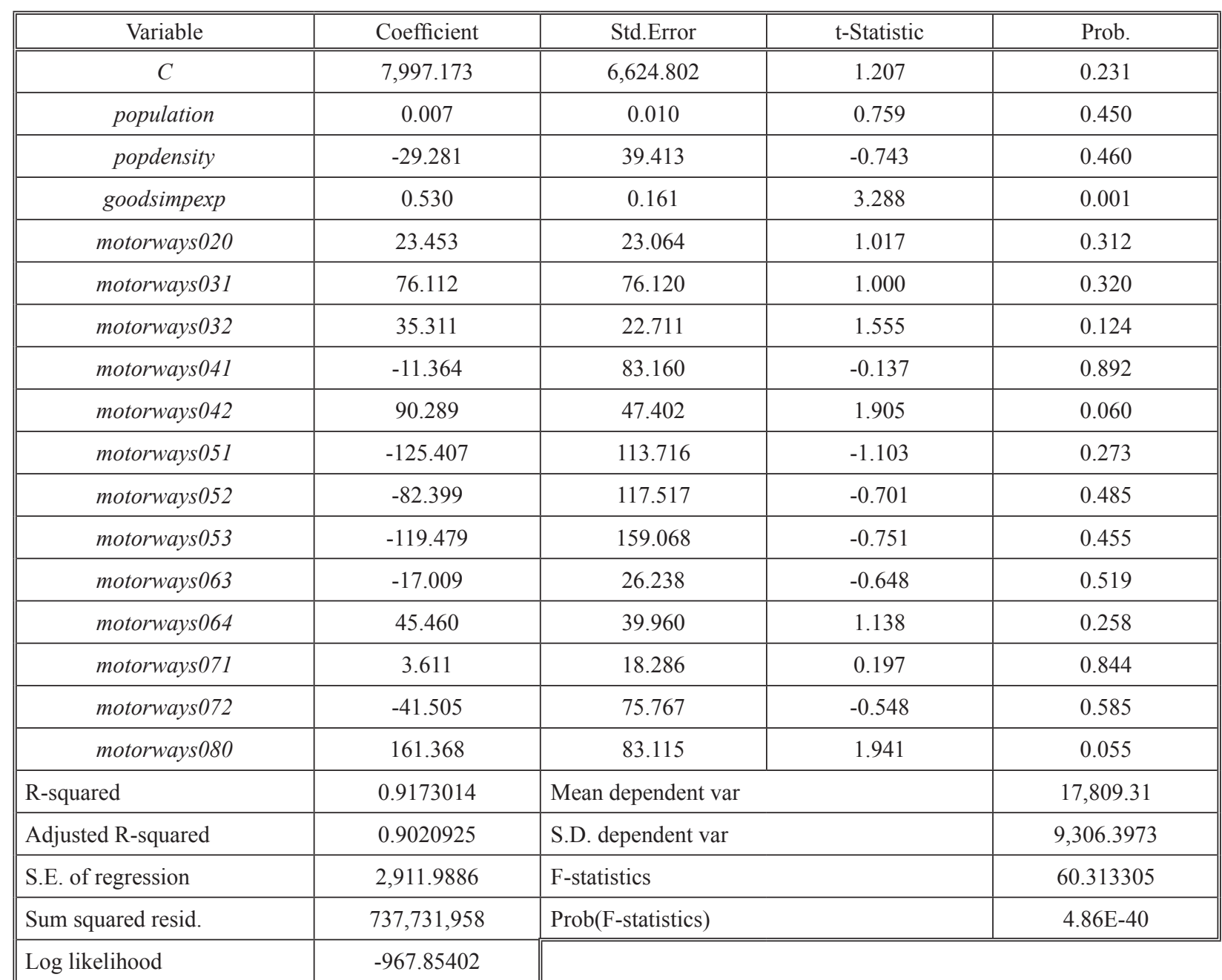

Table 3 - Reduced form estimation of goods transported within the region

\begin{tabular}{|c|c|c|c|c||}
\hline Variable & Coefficient & Std. Error & t-Statistic & Prob. \\
\hline \hline population & $6,803.745$ & $2,215.798$ & 3.071 & 0.003 \\
\hline popdensity & 0.009 & 0.005 & 1.797 & 0.075 \\
\hline goodsimpexp & -37.874 & 16.768 & -2.259 & 0.026 \\
\hline motorways020 & 0.579 & 0.133 & 4.366 & 0.000 \\
\hline motorways031 & 20.305 & 9.418 & 2.156 & 0.034 \\
\hline motorways032 & 87.634 & 42.559 & 2.059 & 0.042 \\
\hline motorways042 & 41.180 & 12.361 & 3.332 & 0.001 \\
\hline motorways064 & 101.109 & 21.157 & 4.779 & 0.000 \\
\hline motorways080 & 47.678 & 17.553 & 2.716 & 0.008 \\
\hline R-squared & 171.719 & 34.846 & 4.928 & 0.000 \\
\hline Adjusted R-squared & 0.913 & Mean dependent var & & $17,809.310$ \\
\hline S.E. of regression & 0.904 & S.D. dependent var & & $9,306.397$ \\
\hline Sum squared resid & $2,878.510$ & F-statistic & & 109.181 \\
\hline Log likelihood & $778,867,281.201$ & Prob(F-statistic) & & $8.95 \mathrm{E}-46$ \\
\hline
\end{tabular}


would have no significant impact on the volume of freight transported in those regions. It is likely that these regions currently face little or no constraint in freight transport related to motorway access. This is an expected result, given that some regions are likely constrained by their lack of motorway networks and other regions are unconstrained, with no correlation between motorways and freight transport.

To improve the statistical efficiency, the model was reduced to exclude motorway variables for regions $41,51,52,53,63,71$, and 72 that were uncorrelated with the dependent variable, and thus provided no explanatory power to the model. The reduction was accomplished in a stepwise fashion by excluding the motorways variable for regions whose coefficients in Table 2 were least significant a few at a time to allow the coefficients and standard errors of the remaining regions to stabilize. The re-estimation of the model appears in Table 3 where the standard errors for the remaining variables declined dramatically, providing more precise estimates of the coefficients.

\section{DISCUSSION}

The interpretation of coefficients from the reduced-form estimation in Table 3 is as follows. The population coefficient is statistically significant at a 90 percent confidence level with a small coefficient. Based on the coefficient, an increase in regional population of 10,000 would increase freight transport within the region by 90,000 tons. Population is used as a control variable in the model to improve the quality of estimates for the hypothesis tests.

The population density has a negative coefficient of -37.874 and it is statistically significant at the 95 percent confidence level. This disproves H1(Null), that population density is uncorrelated with the volume of freight hauled within the region, and supports $\mathrm{H} 1$ (Alt), that the population density negatively affects the freight volume within the region. The authors' interpretation of this result is that higher population density will create congestion that interferes with the hauling of freight. As an example of the magnitude of this effect, an increase in population density of 5 people per square $\mathrm{km}$ is estimated to result in a decrease in total freight hauled inside the region in the amount of 189,000 tons.

The goodsimpexp, which represents the movement of goods across regional borders, has a coefficient of 0.579 at the 99 percent confidence level. Thus, for every 10,000 additional tons of freight that moves across the border, an estimated 5,790 additional tons moves within the region. This result suggests some form of complementarity between the goods moving within the region and the goods moving across regional borders. Both $\mathrm{H} 2$ (Null) and $\mathrm{H} 2$ (Alt-1) are rejected in favour of H2(Alt-2) which supports a positive correlation between the movement of freight within a region and the movement of freight between that region and other regions.

The third hypothesis is tested at the regional level. For regions 41, 51, 52, 53, 63, 71, and 72, $\mathrm{H} 3$ (Null) was not rejected in the initial regression reported in Table 2. For each of these regions, the motorway coefficient was not found to be significantly different from zero. This implies that for each of these regions, adding new motorways would have a statistically insignificant effect on the volume of freight hauled within the region, and it would have little economic value to the local economy.

The South Bohemia Region (031) may be used to illustrate the effects of motorway infrastructure constraints on the movement of freight within the region, and the likelihood that the current availability of motorways may be insufficient for the freight volume expected in the local economy. The data used in this example are from the raw data for the South Bohemia Region in the dataset used to estimate the model. The South Bohemia Region has a very low population density of 63.46 people per square kilometre, which suggests a very low likelihood that the population density is causing congestion across the region. Correspondingly, the South Bohemia Region also has a somewhat low length of motorways at $47 \mathrm{~km}$, but the mean of goods transported within the region, 17,486 thousand tons, is similar to the average for all regions at 17,809 . The coefficient of 87.63 on motorways 031 suggests a $10 \mathrm{~km}$ increase in motorway infrastructure in South Bohemia that would facilitate an increase in within-region transport of goods in the range of 876 thousand tons per year, representing a five percent increase above the average. This suggests a significant constraint in motorway infrastructure in the South Bohemia region that is unlikely to be accounted for by population density, and supports H3(Alt) over H3(Null).

For each of the regions with motorway variables in Table 3 (regions 20, 31, 32, 42, 64, and 80) the regression coefficient for the motorway variable provides an estimate of how many additional thousands of tons of freight are likely to be transported within the region as a result of a one-kilometre increase in 
regional motorway infrastructure. The statistically significant values range from 20.3 for Central Bohemia to 171.7 for Moravia-Silesia, suggesting a wide range of potential impacts of motorway construction by regions. For each $10-\mathrm{km}$ increase in the motorway infrastructure, Central Bohemia is estimated to experience an increase in within-region freight volume of 203 thousand tons per year, while Moravia-Silesia, for the same increase in motorway infrastructure, would experience an increase of 1,717 thousand tons per year, a seven-fold difference.

\section{CONCLUSION}

The policymakers' problem in allocating funds for infrastructure includes the desire to maximize the impact of infrastructure projects on economic activity. This analysis views that policy problem from the perspective of facilitating the transport of freight volume. After controlling the effects of population and population density on freight volume within the region, this analysis allows us to support the conclusion that freight volume within regions and between regions are complementary, and are likely to benefit together from the improvements in infrastructure. This aids the interpretation of the motorway coefficients for each region as measuring the potential marginal benefits to each region from improvements in infrastructure. Thus, our results suggest that a model of this type can be used to guide the policymakers away from the regions where additional motorway infrastructure is unlikely to add to economic activity (insignificant coefficients), and assists the policymakers in deciding among regions that would benefit from infrastructure projects based on the expected magnitude of the impact (magnitude of significant coefficients).

Although the analysis presented herein is focused on the Czech Republic, the data that were used are readily available across much of the European Union and the results can be replicated to allow individual countries or the European Union to consider the economic outcomes of expensive infrastructure projects in an incremental fashion. An unresolved transportation infrastructure constraint is likely to reduce the competitiveness of the region in question and subsequently cause a spillover effect into the neighbouring regions and EU states. Resolving this problem will improve the efficiency of the flow of goods within and across regions for the benefit of both private and public sectors. The analysis presented is based on multiple correlation rather than a causative model. Further study is necessary to specify more fully the model and evaluate the underlying relationships that drive the demand for infrastructure, including taking the value of freight into consideration. Smaller gains in freight volume may be justified in regions where gains in freight volume are low but gains in the value of freight moved are high. The present analysis is strictly limited to freight volume rather than freight value.

It must also be noted, as discussed in the introduction, that other factors such as pollution, health risks, and traffic accident risks must be taken into consideration when deciding upon infrastructure projects. The path of economic growth and the means of transporting goods may evolve rapidly while large infrastructure projects are underway. That said, the model provides some evidence to support the conclusion that a fairly simple model with available data can be used to differentiate the regions that are constrained in roadway infrastructure from those that are not.

\section{ACKNOWLEDGEMENT}

This work was supported by an internal grant from the Faculty of Economics at the University of South Bohemia in České Budějovice, Number IGS17A1.

JIRI ALINA, Ing., Ph.D. ${ }^{1}$

E-mail: jalina@ef.jcu.cz

RICHARD D. MCGRATH, Ph.D. ${ }^{1,2}$

E-mail: rmcgrath@georgiasouthern.edu

FALTOVÁ LEITMANOVÁ IVANA, doc. Ing., CSc. ${ }^{1}$

(Corresponding author)

E-mail: leitman@ef.jcu.cz

FILIP PETRÁCH, Ing., Ph.D. ${ }^{1}$

E-mail: petrach@ef.jcu.cz

${ }^{1}$ Jihočeská univerzita v Českých Budějovicích

Ekonomická fakulta

Studentská 13, 37005 České Budějovice, Česká republika

${ }^{2}$ Parker College of Business

Georgia Southern University

11935 Abercorn Street, Savannah 31419, Georgia, USA

VYUŽITÍ OMEZENÍ V OBJEMECH

NÁKLADNÍ DOPRAVY PRO IDENTIFIKACI

REGIONÁLNÍ POTǨEBY SILNIČNÍ

\section{INFRASTRUKTURY}

Politické rozhodnutí o př́dělu fondu mezi národní regiony pro dopravní infrastrukturu, obzvláště pro dálnice, čeli rozpočtovým omezením a problémy geografického umistění. Záměr tohoto výzkumu je napomáhat politickým činiteli̊m v efektivním rozdělení zdrojů. Cíl tohoto výzkumu je testovat schopnost omezeného modelu identifikoval 
regiony, jejichž kapacita nákladni dopravy je omezena nedostatkem dálnični infrastruktury. Tento článek provádi analýzu vztahu mezi objemem nákladni dopravy, indikátory poptávky po zboží, indikátory kongesce, a dostupnost dálnic a silnic 1. třídy napřič regiony určit, zda model založený na dostupných datech může informovat politické činitelé, jak efektivně použivat omezené fondy a vyhnout se zbytečnému stavbám. NUTS3 regiony $v$ České republice jsou využity pro odhad predběžného modelu, které může být zobecněn pro použití napřič státy. Analýza nalézá dostatečnou proménlivost napríč regiony v marginálním efektu dálnic na nákladni dopravu pro napomáhání politickým činitelìm v určování, které regiony čelí nejvíce ekonomicky vážným omezením, a odděluje efekty hustoty obyvatelstva od nedostatku infrastruktury. Ačkoli Česká republika je rozvinutá země existuje významný důraz, kvůli rostoucím objemům nákladní dopravy a jejím tokỉm, pro analyzování dopravy ve vztahu $k$ využitím územím.

\section{KLÍČOVÁ SLOVA}

politika dopravní infrastruktury; nákladní doprava; poptávka po dopravě; ekonomika dopravy; silnice a dálnice; Česká republika; regionální ekonomika; NUTS3;

\section{REFERENCES}

[1] Załoga E, Milewski D. The impact of transport on regional development. Research Papers Of The Wroclaw University Of Economics / Prace Naukowe Uniwersytetu Ekonomicznego We Wroclawiu. 2013;(286): 71-78.

[2] Knaap T, Oosterhaven J. Spatial economic impacts of transport infrastructure investments. In: Nellthorp J, Mackie P. (ed). Transport Projects, Programmes and Policies. Abingdon on Thames, UK: Routledge; 2017. p. 87-105.

[3] Williams K. Spatial planning, urban form and sustainable transport: An introduction. In: Williams K. (ed). Spatial Planning, Urban Form and Sustainable Transport. Abingdon on Thames, UK: Routledge; 2017. p. 15-28.

[4] Klufova R, Friebelova J, Leitmanová IF. Normative economics or improvement of economic life at regional level in the Czech Republic. AGRIS on-line Papers in Economics and Informatics. 2010;2(4): 1-14.

[5] Sapkota JB. Access to Infrastructure and Human Development: Cross-Country Evidence. JICA-RI Working paper, 2014.

[6] Hulten CR. Infrastructure capital and economic growth: How well you use it may be more important than how much you have (No. w5847). National Bureau of Economic Research; 1996.

[7] Button KJ, Reggiani A. Transportation and economic development challenges. Northampton: Edward Elgar Publishing; 2011.

[8] Gibbons S, Lyytikäinen T, Overman HG, Sanchis-Guarner R. New road infrastructure: The effects on firms. SERC Discussion Papers, SERCDP117. Spatial Economics Research Centre (SERC); 2016.
[9] Terenteva K, Vagizova V, Selivanova K. Transport infrastructure as a driver of sustainable development of regional economic systems. Academy of Strategic Management Journal. 2016;15: 85-93.

[10] Volek T, Novotná M. Branches productivity in the crisis period. $6^{\text {th }}$ International Days of Statistics and Economics; 2012. p. 1199-1209.

[11] Talpur MAH, Napiah M, Chandio IA, Qureshi TA, Khahro SH. Development of a Regional Transport Policy Support System for Rural Planning Agencies in Developing World. Procedia Engineering. 2014;77: 2-10. Available from: doi:10.1016/j.proeng.2014.07.003 [Accessed 23rd Feb 2020].

[12] Deng T. Impacts of Transport Infrastructure on Productivity and Economic Growth: Recent Advances and Research Challenges. Transport Reviews. 2013;33(6): 686-699.

[13] Courtonne JY, Longaretti PY, Dupré D. Uncertainties of Domestic Road Freight Statistics: Insights for Regional Material Flow Studies. Journal of Industrial Ecology. 2018;22(5): 1189-1201.

[14] Alina J. The usage of speed-flow curve at traffic modelling. Proceedings of the $3^{\text {rd }}$ International conference INPROFORUM, 5 - 6 November 2009, Ceske Budejovice, Czech Republic. Ceske Budejovice, Czech Republic: Ekonomicka fakulta, Jihoceska univerzita v Ceskych Budejovicich; 2009. p. 12 -16.

[15] Krisztin T. The determinants of regional freight transport: A spatial, semiparametric approach. Geographical Analysis. 2017;49(3): 268-308.

[16] Kiel J, Smith R, Ubbels B. The Impact of Transport Investments on Competitiveness. Transportation Research Procedia. 2014;1(1): 77-88.

[17] Westin J, Franklin JP, Proost S, Basck P, Raux C. Achieving political acceptability for new transport infrastructure in congested urban regions. Transportation Research Part A: Policy and Practice. 2016;88: 286-303. Available from: doi:10.1016/j.tra.2016.04.009 [Accessed 23 ${ }^{\text {rd }}$ Feb 2020].

[18] Šimulčik D, Bošnjak I, Ban I. Development of Traffic Infrastructure in the Croatian Traffic System. Promet Traffic \& Transportation. 1999;11(5): 263-268.

[19] Valdas A, Ruus R, Põldaru R, Roots J. Forecasting road freight transport alternatives for sustainable regional development in estonia. Economic Science For Rural Development Conference Proceedings. 2016;42: 171-178.

[20] Erjavec J, Trkman P, Groznik A. The Trade-Off between Road and Railroad Freight Transport-Cost Benefit Analysis for Slovenia. Economic. 2014;16(1): 63-76.

[21] Griškevičiūtè-Gečienė A, Griškevičienė D. The Influence of Transport Infrastructure Development on Sustainable Living Environment in Lithuania. Procedia Engineering. 2016;134: 215-223.

[22] Serrano-Hernández A, Álvarez P, Lerga I, Reyes-Rubiano L, Faulin J. Pricing and Internalizing Noise Externalities in Road Freight Transportation. Transportation Research Procedia. 2017;27: 325-332.

[23] Doll C, Köhler J, Maibach M, Schade W, Mader S, Gandenberger C, Vanelslander T. The grand challenge: Pathways towards climate neutral freight corridors. Working Paper 1 of the study LowCarb RFC European Rail Freight Corridors going Carbon Neutral, supported 
by Stiftung Mercator and the European Climate Foundation. Fraunhofer ISI and IML, INFRAS, TPR and M Five. Karlsruhe; 2017.

[24] Grazi F, van den Bergh JC. Spatial organization, transport, and climate change: Comparing instruments of spatial planning and policy. Ecological Economics. 2008;67(4): 630-639.

[25] Bortas I, Brnjac N, Dundović Č. Transport Routes Optimization Model Through Application of Fuzzy Logic. Promet-Traffic \& Transportation. 2018;30(1): 121-129.

[26] Kopits E, Cropper M. Traffic fatalities and economic growth. World Bank Policy Research Working Paper.
Washington D. C.: World Bank; 2003.

[27] Lee RJ, Sener IN, Mullins JA. An evaluation of emerging data collection technologies for travel demand modeling: From research to practice. Transportation Letters. 2016;8(4): 181-193. Available from: doi:10.1080/19427 867.2015.1106787 [Accessed 23 ${ }^{\text {rd }}$ Feb 2020].

[28] Mohmand YT, Wang A, Saeed A. The impact of transportation infrastructure on economic growth: empirical evidence from Pakistan. Transportation Letters. 2016;9(2): 63-69. Available from: doi:10.1080/19427867.2016.116 5463 [Accessed 23 ${ }^{\text {rd }}$ Feb 2020]. 